\title{
Spectral Characterization and 3D Molecular Modeling Studies of Metal Complexes Involving the O, N-Donor Environment of Quinazoline-4(3H)-one Schiff Base and Their Biological Studies
}

\author{
Kuruba Siddappa, ${ }^{1}$ Sunilkumar B. Mane, ${ }^{1}$ and Deene Manikprabhu ${ }^{2}$ \\ ${ }^{1}$ Department of Post-Graduate Studies and Research in Chemistry, Gulbarga University, Gulbarga, Karnataka 585 106, India \\ ${ }^{2}$ Department of Microbiology, Gulbarga University, Gulbarga, Karnataka 585 106, India \\ Correspondence should be addressed to Kuruba Siddappa; siddappa_65@rediffmail.com
}

Received 31 August 2013; Accepted 14 November 2013; Published 11 February 2014

Academic Editors: B. I. Kharisov, A. I. Matesanz, and A. Uslu

Copyright ( $) 2014$ Kuruba Siddappa et al. This is an open access article distributed under the Creative Commons Attribution License, which permits unrestricted use, distribution, and reproduction in any medium, provided the original work is properly cited.

\begin{abstract}
A simple condensation of 3-amino-2-methylquinazoline-4-one with 2-hydroxy-1-naphthaldehyde produced new tridentate ONO donor Schiff base ligand with efficient yield. The structural characterization of ligand and its $\mathrm{Cu}$ (II), $\mathrm{Ni}$ (II), $\mathrm{Co}$ (II), $\mathrm{Mn}$ (II), $\mathrm{Zn}$ (II), and Cd(II) complexes were achieved by the aid of elemental analysis, spectral characterization such as (UV-visible, IR, NMR, mass, and ESR), and magnetic data. The analytical and spectroscopic studies suggest the octahedral geometries of $\mathrm{Cu}$ (II), $\mathrm{Co}$ (II), $\mathrm{Ni}(\mathrm{II})$ and $\mathrm{Mn}$ (II) complexes and tetrahedral geometry of $\mathrm{Zn}(\mathrm{II})$ and $\mathrm{Cd}(\mathrm{II})$ complexes with the tridentate ONO Schiff base ligand. Furthermore, the conclusions drawn from these studies afford further support to the mode of bonding discussed on the basis of their 3D molecular modeling studies by considering different bond lengths, bond angles, and bond distance. The ligand and its metal complexes evaluated for their antimicrobial activity against Staphylococcus aureus (MTCC number 7443), Bacillus subtilis (MTCC number 9878), Escherichia coli (MTCC number 1698), Aspergillus niger (MTCC number 281), and Aspergillus flavus (MTCC number 277). The MIC of these compounds was found to be most active at $10 \mu \mathrm{g} / \mathrm{mL}$ concentration in inhibiting the growth of the tested organisms. The DNA cleavage activity of all the complexes was studied by gel electrophoresis method.
\end{abstract}

\section{Introduction}

The antimicrobial resistances of the bacterial pathogens are of great anxiety on human health and well-being worldwide $[1,2]$. In the treatment of animal and human patients with infectious disease antimicrobial resistance is considered to be a major problem. Recently a growing body of the literature has highlighted the dynamic nature of antimicrobial resistance in community pathogens [3]. Therefore to overcome the alarming problem of microbial resistance to antibiotics, the discovery of novel active compounds against new targets is a matter of urgency. Previously it was reported that quinazoline-4- $(3 \mathrm{H})$-one derivatives have interesting antimicrobial activity against different species of gram-positive, gram-negative, and pathogenic fungi [4].
The extensive literature survey on heterocyclic compounds of Schiff bases and their metal complexes have been discussed by several researchers in coordination chemistry [5]; Schiff base ligands containing $\mathrm{O}, \mathrm{N}$-donor atoms have played a promising role in coordination chemistry owing to their remarkable complex forming ability with various metal ions. The formation of metal complexes with these Schiff base ligands is becoming increasingly important as biochemical, biomedical, analytical, and antimicrobial reagents [6].

Quinazoline-4 $(3 \mathrm{H})$ is one of the most frequently encountered heterocycles in medicinal chemistry, which contains a pyrimidine nucleus in their structure, which often leads to pronounced biological and pharmaceutical activities especially antibacterial, antifungal, anti-inflammatory, anticancer, anticonvulsant, antioxidant, antitubercular, anti-HIV, and 
analgesic [7]. In addition, many substituted quinazoline derivatives have recently earned great interest in chemotherapy as antitumor drugs [8]. On the other hand, 2-hydroxy Schiff bases formed by condensation reactions of 2-hydroxy1-naphthaldehyde with various amines have been extensively studied due to their wide applications particularly in pharmaceutical field [9]. In recent years people pay great interest in theoretical calculations of various Schiff base transition metal complexes in which interns played a fundamental role in the development of coordination compounds and also is helpful in designing and identification of new biological and chemotherapeutic agents [10].

In the absence of an X-ray crystal structure data the 3-dimensional structure of the molecules cannot be completely unambiguous. However, recent major advances in the computational chemistry tools provide an alternative, albeit approximate, approach for obtaining the three-dimensional structure of the compounds. Computational chemistry may be defined as the application of mathematical and theoretical principles to the solution of chemical problems [11]. Molecular modeling, a subset of computational chemistry, concentrate on predicting the behaviour of individual molecules within a chemical system. The most accurate molecular models use an initial or (first principles) electronic structure methods, based upon the principles of quantum mechanics, and generally vary computer intensive. Due to advances in computer storage capacity and processor performance, molecular modelling emerged as an interactive graphics program and has been a rapidly evolving and expanding field to the point that it is now possible to solve relevant problems in an acceptable amount of time that is. It allows rapid structure building, geometry optimization with minimum energy, and molecular display. It has the ability to handle transition metal and inner transition metal complexes $[12,13]$. Theoretical calculations have paid a considerable attention to the characterization and inferences of geometrical optimization of the prepared complexes and it also enables the calculation of the actual bond lengths, angles, and total static energy of a molecule in terms of deviations from reference unstrained bond lengths, angles, and torsions plus nonbonded interactions $[14,15]$.

Hence in view of the analytical and biological importance of quinazoline- $4(3 \mathrm{H})$ and as a part of our continued work on the chemistry of quinazoline- $4(3 \mathrm{H})$-one ring system [16], the present work deals with the synthesis and characterization of a new (E)-3-((2-hydroxynaphthalen-1-yl)methleneamino)-2methylquinazoline-4(3H)-one HNMAMQ to be designed with various potential ligating sites by suitably orienting the groups such as $\mathrm{N}, \mathrm{O},>\mathrm{C}=\mathrm{N}$, and $\mathrm{OH}$ for tridentate chelation with $\mathrm{Cu}(\mathrm{II}), \mathrm{Co}(\mathrm{II}), \mathrm{Ni}(\mathrm{II}), \mathrm{Mn}(\mathrm{II}), \mathrm{Zn}(\mathrm{II})$, and $\mathrm{Cd}(\mathrm{II})$ complexes in a way to produce interesting core structures.

In addition to that the available literature survey stimulated our interest to obtain structural information, optimized geometry of ligand HNMAMQ, and its complexes by computing the minimum satiric energy and the theoretical physical parameters, such as bond length and bond angles using MM2CS Chem 3D Ultra 11.0 version molecular modeling program; these models are necessary to obtain a constant, more precise picture of the biological active molecule at the atomic level and furthermore provide new insights that can be used to design novel therapeutic agents. The ligand HNMAMQ and its complexes were screened for their antimicrobial and DNA cleavage activities to check their biological potency.

\section{Experimental}

2.1. General Methods and Materials. All the reagents were commercially obtained from Hi-media (India). Elemental analysis $(\mathrm{C}, \mathrm{H}$, and $\mathrm{N})$ was carried out using Flash EA 1112 series elemental analyzer. Infrared spectra of the ligand and its metal complexes in $\mathrm{KBr}$ pellets were recorded in the spectral range $4000-350 \mathrm{~cm}^{-1}$ using Perkin Elmer Spectrumone FT-IR spectrometer. UV-visible spectra were recorded in the range $200-1100 \mathrm{~nm}$ on Elico SL-164 double beam UV-Vis spectrophotometer. The ${ }^{1} \mathrm{H}$ NMR spectra were recorded on AMX-400 NMR spectrometer, using TMS as internal standard and DMSO as a solvent. ${ }^{13} \mathrm{C}$ NMR spectra were recorded on Bruker ACF- $125 \mathrm{MHz}$ spectrometer. Mass spectra were recorded with a JEOL GC MATE II GC-MS mass spectrometer. Magnetic susceptibilities were measured on a Guoy balance at room temperature using $\mathrm{Hg}\left[\mathrm{Co}(\mathrm{NCS})_{4}\right]$ as calibrant. The molar conductance data were recorded on the ELICO-CM-82T conductivity bridge in DMF solution at concentration $\sim 10^{-3} \mathrm{M}$ and ESR spectra were recorded on Bruker Biospin. Interaction of metal complexes with DNA of E. coli was done in $0.01 \mathrm{M}$ buffer ( $\mathrm{pH} 7.2)$.

2.2. Chemistry. A simple and efficient synthetic strategy is employed for the preparation of new (E)-3-((2-hydroxynaphthalen-1-yl)methyleneamino)-2-methylquinazoline-4(3H)one HNMAMQ Schiff base ligand as presented in Scheme 1, by involving the following three steps.

Step 1 (preparation of 2-methyl-4H-benzo[d][1,3]oxazin-4one). When a hot solution of methyl anthranilate reacts with acetic anhydride in $20 \mathrm{~mL}$ methanol results in the formation of a cyclic compound 2-methyl-4H-benzo[d] [1,3] oxazin-4one as a white silvery needle (see Scheme 1).

Step 2 (preparation of 3-amino-2-methylquinazoline-4(3H)one). In Step 2 the reaction of 2-methyl-4H-benzo[d] [1,3] oxazin-4-one with hydrazine in $20 \mathrm{~mL}$ hot methanol gives 3amino-2-methylquinazoline-4(3H)-one [17] (see Scheme 2).

Step 3 (preparation of (E)-3-((2-hydroxynaphthalen-1-yl)methyleneamino)-2-methylquinazoline-4(3H)-one HNMAMQ Schiff base ligand). In Step 3 a simple condensation reaction between 3-amino-2-methyl quinazoline-4-one and 2-hydroxy-1-naphthaldehyde results in the formation of new Schiff base ligand with higher yield as presented in Scheme 3.

2.3. Synthesis of Ligand HNMAMQ. The synthetic route for the preparation of tridentate ligand HNMAMQ is as follows.

A $25 \mathrm{~mL}$ methanolic solution of both 3-amino-2methylquinazoline-4-one (1.75 g, $0.01 \mathrm{~mol})$ and 2-hydroxy-1naphthaldehyde $(1.72 \mathrm{~g}, 0.01 \mathrm{~mol})$ was taken in $100 \mathrm{~mL}$ round bottom flask and heated to reflux for about $4-5 \mathrm{~h}$ on a water 


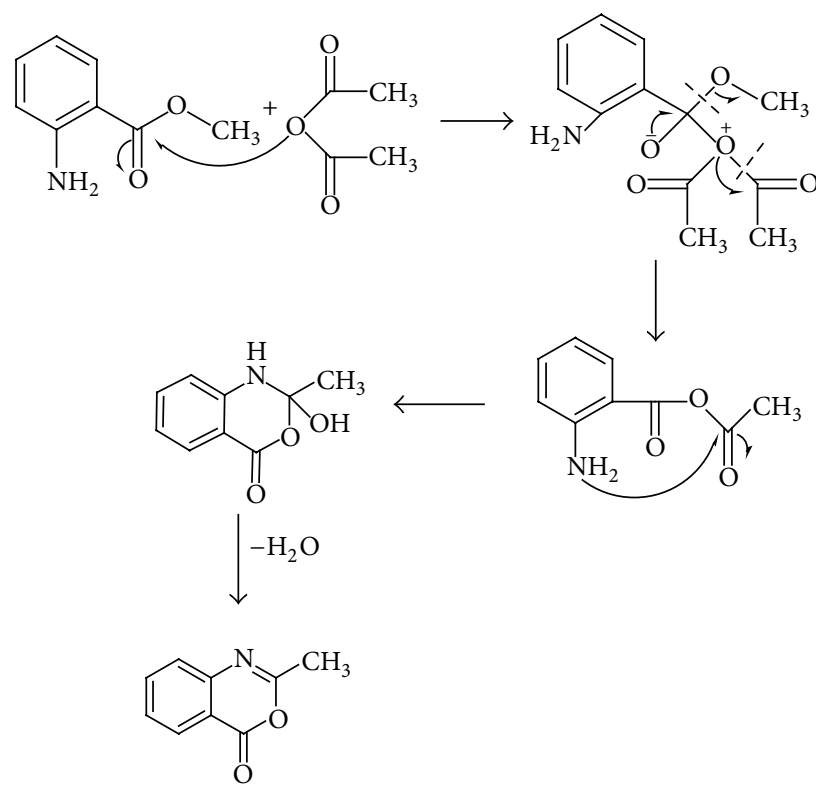

2-Methyl-4H-benzo[d][1,3]oxazin-4-one

SCHEME 1<smiles>CC1=Nc2ccccc2C(=O)CCCCCC1</smiles><smiles>CC1=Nc2ccccc2C(O)(NN)C1</smiles><smiles>Cc1nc2ccccc2c(=O)n1N</smiles><smiles>[CH]CC</smiles><smiles>C/C(O)=N/c1ccccc1C(=O)NN</smiles>

3-Amino-2-methylquinazoline-4(3H)-one

SCHEME 2

bath. The progress of the reaction was continuously checked with the aid of TLC. The coloured solid product obtained from the above reaction after evaporation of the solvent was filtered, washed with cold methanol, and recrystallized from hot methanol, to get ligand HNMAMQ, as presented in Scheme 3.

2.4. Synthesis of Metal(II) Complexes. A familiar method is used for the synthesis of metal complexes by using reaction between metal salts and ligand in a molar ratio $(\mathrm{M}: \mathrm{L}=1: 1$ and $1: 2)$. An alcoholic solution of ligand HNMAMQ (35 mL, $0.01 \mathrm{mmol}$ ) and $\mathrm{Cu}(\mathrm{II}), \mathrm{Ni}(\mathrm{II}) \mathrm{Co}(\mathrm{II}), \mathrm{Mn}(\mathrm{II}), \mathrm{Zn}(\mathrm{II})$, and Cd(II) chlorides $(10 \mathrm{~mL}, 0.01 \mathrm{mmol})$ were mixed vigorously and heated to reflux for $3 \mathrm{~h}$. The volume of the reaction mixture was reduced to one-half by evaporation of solvent. Furthermore $0.5 \mathrm{~g}$ of sodium acetate was added to the reaction mixture to adjust the $\mathrm{pH} 7-8$ followed by refluxing for about $2 \mathrm{~h}$ more. The solid thus obtained after cooling was filtered, washed thoroughly with hot methanol to apparent dryness, and finally dried in vacuum over fused $\mathrm{CaCl}_{2}$.

2.5. Study of Complex Formation in Solution. The complexes of the ligand HNMAMQ with metal ions were studied in DMF, in order to determine the $\mathrm{M}: \mathrm{L}$ ratio in the complex following the molar ratio method. A series of solutions were prepared having a constant concentration $\left(10^{-3} \mathrm{M}\right)$ of the metal ions and (L). The $\mathrm{M}: \mathrm{L}$ ratio was determined by the relationship between the absorption of light and the molar ratio of $\mathrm{M}: \mathrm{L}$. The results of complex formation in solution were presented in Table 1.

\subsection{Biological Studies}

2.6.1. DNA Cleavage Studies. Preparation of culture media for the DNA cleavage studies of metal complexes and the isolation of DNA were carried out according to the literature procedure [18]. 
<smiles>Cc1nc2ccccc2c(=O)n1N</smiles>

3-Amino-2-methylquinazoline-4(3H)-one<smiles>O=Cc1c(O)ccc2ccccc12</smiles>

2-Hydroxy-1-naphthaldehyde<smiles>Cc1nc2ccccc2c(=O)n1/N=C/c1c(O)ccc2ccccc12</smiles>

(E)-3-((2-Hydroxynaphthalen-1-yl)methyleneamino)-2-methylquinazoline-4(3H)-one

HNMAMQ

Scheme 3: Synthetic route for the preparation of ligand HNMAMQ.

2.6.2. Agarose Gel Electrophoresis. The DNA cleavage products were analyzed by agarose gel electrophoresis method [18]. The test solution of metal complexes was prepared by dissolving $10 \mathrm{mg}$ of the compound in $10 \mathrm{~mL}$ of DMSO. The sample $(25 \mu \mathrm{g} / \mathrm{mL})$ was added to the isolated DNA of E. coli. The samples were incubated for $2 \mathrm{~h}$ at $37^{\circ} \mathrm{C}$, and then $20 \mu \mathrm{L}$ of DNA sample (mixed with bromophenol blue dye at a 1:1 ratio) was loaded carefully into the electrophoresis chamber wells along with a standard DNA marker in TAE buffer (4.84 g Tris base, $\mathrm{pH}$ 8.0; 0.5 M EDTA/1 L). Then a constant electricity $(120 \mathrm{~V})$ was applied for about $30 \mathrm{~min}$. Finally, the gel was removed and stained with $10 \mu \mathrm{g} / \mathrm{mL}$ of ethidium bromide for 10-15 min. The bands obtained were observed under the Vilber Lourmate gel documentation system and photographed to determine the extent of DNA cleavage. Then the results were compared with standard DNA marker.

2.6.3. In Vitro Antimicrobial Activities. All the microorganisms used in the antimicrobial analysis were collected from microbial type culture collection (MTCC), Chandigarh, India. The antimicrobial activities of the ligand HNMAMQ and its complexes were tested against three bacteria and two fungi, such as (Staphylococcus aureus (MTCC number 7443), Bacillus subtilis (MTCC number 9878), Escherichia coli (MTCC number 1698), Aspergillus niger (MTCC number 281), and Aspergillus flavus (MTCC number 277)), respectively. To evaluate the antimicrobial activity we determined the minimum inhibitory concentration (MIC). The MIC was determined by taking different volumes $(5,10,15,20,25$, $30,35,40,45$, and $50 \mu \mathrm{L})$ of same concentrations $(1 \mathrm{mg} / \mathrm{mL})$ of HNMAMQ and its complexes were added to MullerHinton broth containing the test organisms (maintained at $10^{6} \mathrm{CFU} / \mathrm{mL}$ ) and incubated at $37^{\circ} \mathrm{C}$ for $24 \mathrm{~h}$ (bacteria) and $48 \mathrm{~h}$ (fungi). The MIC was determined by measuring the optical density at $625 \mathrm{~nm}$.

\section{Results and Discussion}

In the present investigation, the new Schiff base ligand HNMAMQ and its $\mathrm{Cu}(\mathrm{II}), \mathrm{Ni}(\mathrm{II}), \mathrm{Co}(\mathrm{II}), \mathrm{Mn}(\mathrm{II}), \mathrm{Zn}(\mathrm{II})$, and $\mathrm{Cd}$ (II) complexes were synthesized by treating metal ions with ligand HNMAMQ. The evidence for the formation of tridentate ONO donor nature of ligand HNMAMQ was confirmed by using various spectral techniques (UVvisible, IR, NMR, and mass spectra). The analytical data and physical properties showed that the ligand HNMAMQ and its complexes were very stable and nonhygroscopic at room temperature. All the metal complexes were sparingly soluble in common organic solvents and show complete solubility in DMF and DMSO. The measured molar conductance values of the complexes were within the range of 9$20 \mathrm{Ohm}^{-1} \mathrm{~cm}^{2} \mathrm{Mol}^{-1}$ showing their nonelectrolytic nature [15]. Based on analytical and spectral studies, $\mathrm{Cu}$ (II), Ni(II) $\mathrm{Co}(\mathrm{II})$, and $\mathrm{Mn}$ (II) exhibits octahedral structures, while $\mathrm{Zn}$ (II) and Cd(II) complexes exhibits tetrahedral structures, where L stands for deprotonated legend. The metal content of the complexes was analyzed by decomposing with a mixture of $\mathrm{HNO}_{3}$ and $\mathrm{HCl}$ followed by $\mathrm{H}_{2} \mathrm{SO}_{4}$. The chloride was determined as $\mathrm{AgCl}$ by following a standard procedure 


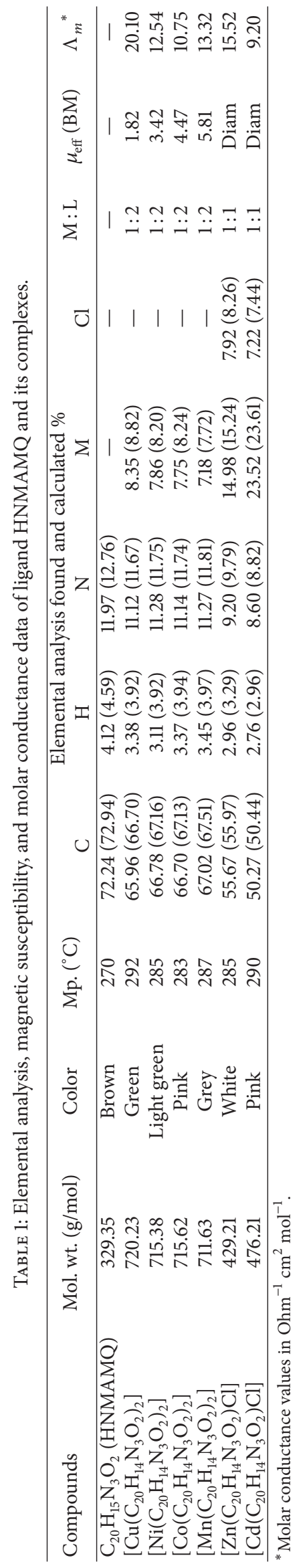


TABLE 2: The infrared frequencies (in $\mathrm{cm}^{-1}$ ) of ligand HNMAMQ and its complexes.

\begin{tabular}{lcccccc}
\hline Compounds & $v_{\mathrm{OH} / \mathrm{H}_{2} \mathrm{O}}$ & $v_{\mathrm{C}=\mathrm{O}}$ & $v_{\mathrm{C}=\mathrm{N}}$ & $v_{\mathrm{C}-\mathrm{O}}$ & $v_{\mathrm{M}-\mathrm{O}}$ & $v_{\mathrm{M}-\mathrm{N}}$ \\
\hline $\mathrm{C}_{20} \mathrm{H}_{15} \mathrm{~N}_{3} \mathrm{O}_{2}(\mathrm{HNMAMQ})$ & 3425 & 1720 & 1598 & 1287 & - & - \\
{$\left[\mathrm{Cu}\left(\mathrm{C}_{20} \mathrm{H}_{14} \mathrm{~N}_{3} \mathrm{O}_{2}\right)_{2}\right]$} & - & 1705 & 1580 & 1312 & 550 & - \\
{$\left[\mathrm{Ni}\left(\mathrm{C}_{20} \mathrm{H}_{14} \mathrm{~N}_{3} \mathrm{O}_{2}\right)_{2}\right]$} & - & 1714 & 1582 & 1310 & 545 & 460 \\
{$\left[\mathrm{Co}\left(\mathrm{C}_{20} \mathrm{H}_{14} \mathrm{~N}_{3} \mathrm{O}_{2}\right)_{2}\right]$} & - & 1695 & 1590 & 1317 & 552 & - \\
{$\left[\mathrm{Mn}\left(\mathrm{C}_{20} \mathrm{H}_{14} \mathrm{~N}_{3} \mathrm{O}_{2}\right)_{2}\right]$} & - & 1698 & 1578 & 1304 & 547 & 455 \\
{$\left[\mathrm{Zn}\left(\mathrm{C}_{20} \mathrm{H}_{14} \mathrm{~N}_{3} \mathrm{O}_{2}\right) \mathrm{Cl}\right]$} & - & 1704 & 1581 & 1311 & 548 & 452 \\
{$\left[\mathrm{Cd}\left(\mathrm{C}_{20} \mathrm{H}_{14} \mathrm{~N}_{3} \mathrm{O}_{2}\right) \mathrm{Cl}\right]$} & - & 1700 & 1584 & 1317 & 553 & 468 \\
\hline
\end{tabular}

[19]. The elemental analysis (C, H, and N) data of ligand HNMAMQ and its complexes were in good agreement with proposed molecular formulas.

3.1. Infrared Spectral Data of Ligand HNMAMQ and Its Complexes. The most prominent infrared bands for the ligand HNMAMQ and its complexes together with their assignments are listed in Table 2. The IR spectra of the ligand HNMAMQ exhibited a broadband in the region of 3425$3372 \mathrm{~cm}^{-1}$ due to the phenolic $\nu(\mathrm{OH})$, a characteristic high intensity band observed in the region of $1598-1592 \mathrm{~cm}^{-1}$ assigned to $\nu(\mathrm{C}=\mathrm{N})$ and a high intensity strong band in the region of $1720-1715 \mathrm{~cm}^{-1}$ assigned to phenolic $v(\mathrm{C}=\mathrm{O})$. Upon complexation with ligand HNMAMQ the IR spectra of metal complexes show the following changes. The absences of broad band due to phenolic $\nu(\mathrm{OH})$ ensure the involvement of phenolic oxygen in complex formation via deprotonation [20]. The band due to $v(\mathrm{C}=\mathrm{N})$ group that was in the region of $1590-1578 \mathrm{~cm}^{-1}$ shows shift to the lower region which can be attributed to delocalisation of metal electron density $\left(t_{2 \mathrm{~g}}\right)$ to the $\pi$-system of the ligand inferred the involvement of azomethine nitrogen [21]. Band appeared in the region of $1714-1704 \mathrm{~cm}^{-1}$ due to $\nu(\mathrm{C}=\mathrm{O})$ indicates the participation of the phenolic oxygen in complexation with metal ion [22]. Furthermore, the metal complexes displayed $v(\mathrm{M}-\mathrm{N})$ and $v(\mathrm{M}-\mathrm{O})$ bands in the regions of $552-545 \mathrm{~cm}^{-1}$ and $460-447 \mathrm{~cm}^{-1}$ which give the evidence for the coordination through carboxylato oxygen and azomethine nitrogen of the ligand HNMAMQ with the metal ions [23, 24]. The diamagnetic $\mathrm{Zn}$ (II) and $\mathrm{Cd}$ (II) complexes exhibit a weak band due to $v(\mathrm{M}-\mathrm{Cl})$ in the region of $357-352 \mathrm{~cm}^{-1}$ which was further confirmed by their quantitative analysis. Thus IR spectral data evidently confirms the coordination of ligand HNMAMQ with different metal ions.

3.2. ${ }^{1} \mathrm{H} N M R$ and ${ }^{13} \mathrm{C} N M R$ Spectral Studies. NMR spectra of ligand HNMAMQ and its $\mathrm{Zn}$ (II) and Cd(II) complexes were carried in DMSO-d6 in the presence of TMS as an internal standard. The ligand HNMAMQ displays a characteristic ${ }^{1} \mathrm{H}$ NMR signal at $\delta 10.61 \mathrm{ppm}(\mathrm{s}, 1 \mathrm{H},-\mathrm{OH})$ due to naphthalene phenolic $-\mathrm{OH}$ proton. The signal due to azomethine proton resonated at $\delta 8.35 \mathrm{ppm}(\mathrm{s}, 1 \mathrm{H},-\mathrm{CH}=\mathrm{N})$ and methyl protons at $\delta 2.41 \mathrm{ppm}\left(\mathrm{s}, 3 \mathrm{H}, \mathrm{CH}_{3}\right)$. The aromatic protons of the ligand HNMAMQ appeared as multiplets in the range of $\delta$ 6.82-8.54 ppm (m, 10H, Ar-H). The ligand HNMAMQ upon complexation with $\mathrm{Zn}$ (II) and $\mathrm{Cd}(\mathrm{II})$ ion shows a disappearance of signal due to phenolic-OH which indicates the involvement of phenolic oxygen [25]. The shift of the signal from $\delta 8.35$ to $\delta 8.41-8.48$ ppm due to azomethine proton indicates the coordination of azomethine nitrogen with metal ion [26]. The $-\mathrm{CH}_{3}$ protons appear at $\delta 2.55-$ $2.60 \mathrm{ppm}$, while the aromatic protons appear as a multiplets in the range of $\delta 6.91-8.61 \mathrm{ppm}$.

The ${ }^{13} \mathrm{C}$ NMR spectrum of ligand HNMAMQ exhibits signals at $\delta 163.32 \mathrm{ppm}, \delta 160.20 \mathrm{ppm}$, and $\delta 171.02 \mathrm{ppm}$ due to azomethine carbon $(\mathrm{HC}=\mathrm{N})$, carbonyl carbon $(\mathrm{C}=\mathrm{O})$, and aromatic carbons (Ar-OH), respectively. However, the ${ }^{13} \mathrm{C}$ NMR spectrum of $\mathrm{Zn}$ (II) and Cd(II) complexes shows a slight shift in their signals and resonates at $\delta 161.41-161.48 \mathrm{ppm}, \delta$ $173.41-173.50 \mathrm{ppm}$, and $\delta 154.82-155.12 \mathrm{ppm}$ mainly due to azomethine carbon $(\mathrm{HC}=\mathrm{N})$ [27], carbonyl carbon $(\mathrm{C}=\mathrm{O})$, and aromatic carbons (Ar-OH), respectively.

Hence, from the above observations it was concluded that the total number of protons and carbons, calculated from the integration curves, and the values obtained from their $\mathrm{C}, \mathrm{H}$, and $\mathrm{N}$ analysis were in agreement with each other.

3.3. UV-Visible Spectral Studies and Magnetic Susceptibility Measurements. The $\mathrm{Cu}(\mathrm{II}), \mathrm{Co}(\mathrm{II}), \mathrm{Ni}(\mathrm{II})$, and $\mathrm{Mn}(\mathrm{II})$ complexes of ligand HNMAMQ were subjected to their UVvisible spectral studies at room temperature in the range of 200-1100 nm by using DMSO as a solvent. The $\mathrm{Cu}$ (II) complex displays a asymmetric broadband at $12530-17020 \mathrm{~cm}^{-1}$. The ${ }^{2} \mathrm{E}_{\mathrm{g}}$ and ${ }^{2} \mathrm{~T}_{2 \mathrm{~g}}$ states of the octahedral $\mathrm{Cu}$ (II) complex split under the influence of tetrahedral distortion and cause three transitions: ${ }^{2} \mathrm{~B}_{1 \mathrm{~g}} \rightarrow{ }^{2} \mathrm{~A}_{1 \mathrm{~g}}\left(\mathrm{~d}_{x^{2}-y^{2}} \rightarrow \mathrm{d}_{z^{2}}\right)\left(v_{1}\right),{ }^{2} \mathrm{~B}_{1 \mathrm{~g}} \rightarrow$ ${ }^{2} \mathrm{~B}_{2 \mathrm{~g}}\left(\mathrm{~d}_{x^{2}-y^{2}} \rightarrow \mathrm{d}_{z y}\right)\left(v_{2}\right)$, and ${ }^{2} \mathrm{~B}_{1 \mathrm{~g}} \rightarrow{ }^{2} \mathrm{E}_{\mathrm{g}}\left(\mathrm{d}_{x^{2}-y^{2}} \rightarrow \mathrm{d}_{z y}\right.$, $\left.\mathrm{d}_{y z}\right)\left(v_{3}\right)$ having equal energy and show only one broad absorption band due to dynamic Jahn-Teller distortion in which interns confirm the distorted octahedral geometry around the $\mathrm{Cu}(\mathrm{II})$ ion [28]. The $\mathrm{Co}(\mathrm{II})$ complex shows two bands at 18337 and $20532 \mathrm{~cm}^{-1}$ due to ${ }^{4} \mathrm{~T}_{\mathrm{lg}}(\mathrm{F}) \rightarrow{ }^{4} \mathrm{~A}_{2 \mathrm{~g}}(\mathrm{~F})\left(\nu_{2}\right)$ and ${ }^{4} \mathrm{~T}_{1 \mathrm{~g}}(\mathrm{~F}) \rightarrow{ }^{4} \mathrm{~T}_{2 \mathrm{~g}}(\mathrm{~F})\left(\nu_{3}\right)$ transitions, showing the octahedral stereochemistry around Co(II) metal ion [29]. However, the lower energy $v_{1}$ band could be calculated by using Underhill and Billing equations [30]. The Ni(II) complex that displays three bands at 8213,15850 , and $20430 \mathrm{~cm}^{-1}$ due to ${ }^{3} \mathrm{~A}_{2 \mathrm{~g}}(\mathrm{~F}) \rightarrow{ }^{3} \mathrm{~T}_{2 \mathrm{~g}}(\mathrm{~F})\left(\nu_{1}\right),{ }^{3} \mathrm{~A}_{2 \mathrm{~g}}(\mathrm{~F}) \rightarrow{ }^{3} \mathrm{~T}_{1 \mathrm{~g}}(\mathrm{~F})\left(\nu_{2}\right)$, and ${ }^{3} \mathrm{~A}_{2 \mathrm{~g}}(\mathrm{~F}) \rightarrow{ }^{3} \mathrm{~T}_{\mathrm{lg}}(\mathrm{P})\left(v_{3}\right)$ transitions reveals the octahedral 
TABLE 3: Ligand field, Sinha, metal-ligand covalency percent, and covalency angular overlap parameters of $\mathrm{Cu}(\mathrm{II}), \mathrm{Ni}(\mathrm{II}), \mathrm{Co}(\mathrm{II})$, and $\mathrm{Mn}$ (II) complexes.

\begin{tabular}{lcccccccccc}
\hline Complexes & $\mathrm{Dq}$ & $B^{\prime}$ & $\beta$ & $\beta \%$ & $\nu_{2} / \nu_{1}$ & $(1-\beta)$ & $b^{1 / 2}$ & $\delta \%$ & $\eta$ & LFSC (Kcal) \\
\hline$\left[\mathrm{Cu}\left(\mathrm{C}_{20} \mathrm{H}_{14} \mathrm{~N}_{3} \mathrm{O}_{2}\right)_{2}\right]$ & 1514 & - & - & - & - & - & - & - & - & 25.25 \\
{$\left[\mathrm{Ni}\left(\mathrm{C}_{20} \mathrm{H}_{14} \mathrm{~N}_{3} \mathrm{O}_{2}\right)_{2}\right]$} & 930 & 891 & 0.91 & 8.2 & 1.92 & 0.09 & 0.15 & 9.89 & 0.31 & 15.94 \\
{$\left[\mathrm{Co}\left(\mathrm{C}_{20} \mathrm{H}_{14} \mathrm{~N}_{3} \mathrm{O}_{2}\right)_{2}\right]$} & 941 & 819 & 0.84 & 15.6 & 1.93 & 0.16 & 0.20 & 19.04 & 0.43 & 16.13 \\
{$\left[\mathrm{Mn}\left(\mathrm{C}_{20} \mathrm{H}_{14} \mathrm{~N}_{3} \mathrm{O}_{2}\right)_{2}\right]$} & 912 & 944 & 0.97 & 2.7 & 1.87 & 0.03 & 0.08 & 3.09 & 0.17 & 15.63 \\
\hline
\end{tabular}

geometry around the $\mathrm{Ni}(\mathrm{II})$ ion [31]. The $\mathrm{Mn}(\mathrm{II})$ complex that exhibits bands at 10120,19010, and $21820 \mathrm{~cm}^{-1}$ assigned due to ${ }^{6} \mathrm{~A}_{\mathrm{lg}} \rightarrow{ }^{4} \mathrm{~T}_{\mathrm{lg}}\left(\nu_{1}\right),{ }^{6} \mathrm{~A}_{\mathrm{lg}} \rightarrow{ }^{4} \mathrm{~T}_{2 \mathrm{~g}}\left(\nu_{2}\right)$, and ${ }^{6} \mathrm{~A}_{\mathrm{lg}} \rightarrow{ }^{4} \mathrm{E}_{\mathrm{g}}\left(\nu_{3}\right)$ transition indicates the coordinated octahedral geometry [32].

Table 1 shows the measured magnetic moment values of $\mathrm{Cu}(\mathrm{II}), \mathrm{Co}(\mathrm{II}), \mathrm{Ni}(\mathrm{II})$, and $\mathrm{Mn}(\mathrm{II})$ complexes in the range of 1.80-1.85 BM, 3.34-3.62 BM, 4.39-4.60 BM, and 5.62$5.90 \mathrm{BM}$, respectively, and indicates their octahedral geometries [33]. Furthermore, the values of electronic parameters such as the Racah interelectronic repulsion parameter $\left(B^{\prime}\right)$, covalency factor $(\beta)$, ligand field splitting energy (10 Dq), and ligand field stabilization energy (LFSE) [34] were summarized in Table 3 . In addition, from the values of $\beta$, the Covalence factors $\left(b^{1 / 2}\right)$, Sinha parameter $(\delta \%)$, that is, Metalligand covalency percent, and the covalency angular overlap parameter $(\eta)$ have been calculated using the following three expressions [35]:

$$
\begin{gathered}
b^{1 / 2}=\frac{1}{2}\left[(1-\beta)^{1 / 2}\right], \quad \delta(\%)=\left[\frac{(1-\beta)}{\beta}\right] \times 100, \\
\eta=\frac{\left[\left(1-\beta^{1 / 2}\right)\right]}{\beta^{1 / 2}} .
\end{gathered}
$$

The positive values for $(1-\beta), b^{1 / 2}, \delta \%$, and $\eta$ indicate strong covalent bonding between ligand HNMAMQ and its complexes.

3.4. Mass Spectral Studies. The mass spectrum of ligand HNMAMQ shows the formation of a molecular ion peak at $m / z=329[\mathrm{M}]^{+}$equivalent to its total molecular weight. The mass spectrum of $\mathrm{Zn}$ (II) complex shows the molecular ion peaks at $m / z=429[\mathrm{M}]^{+}$and $431[\mathrm{M}+2]^{+}$which were in good agreement with the expected values, supporting the composition of the complex.

3.5. Electron Spin Resonance (ESR) Spectra of Cu(II) Complex. The ESR spectrum pattern of $\mathrm{Cu}(\mathrm{II})$ complex gave the following data $\mathrm{g}_{\|}=2.23$ and $\mathrm{g}_{\perp}=2.05, \mathrm{~g}_{\mathrm{av}}=2.11$ and $\mathrm{g}_{\text {iso }}=$ 2.17. The observed $g_{\|}$value was less than 2.3 , in accordance with the covalent character of the metal-ligand bond. The ESR spectra showed asymmetric bands with $\mathrm{g}_{\|}>\mathrm{g}_{\perp}>2.0023$, suggest the presence of unpaired electron in $\mathrm{d}_{x^{2}-y^{2}}$ orbit, and indicate the octahedral geometry around $\mathrm{Cu}$ (II) ion [36]. The $\mathrm{G}$ parameter was calculated by using a formula $\mathrm{G}=\left(\mathrm{g}_{\|}-\right.$ $2.0023) /\left(g_{\perp}-2.0023\right)$ which measures the negligible exchange interaction between the metal centres in polycrystalline solid.

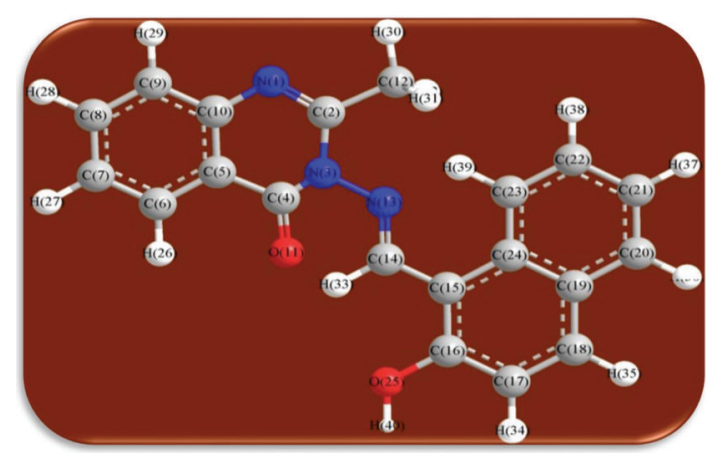

FIGURE 1: Molecular modeling structure of ligand HNMAMQ.

In the present study the $\mathrm{Cu}(\mathrm{II})$ complex which shows $\mathrm{G}=4.77$ which was greater than 4 indicates the negligible exchange interaction in solid complex as suggested by Hathaway and Billing [37].

3.6. Molecular Modeling Studies of Ligand HNMAMQ and Its Complexes. An attempt to gain better insight on the molecular structure of the ligand and its complexes, geometric optimization, conformational analysis, and 3D molecular modeling of the proposed structure of the ligand HNMAMQ and its complexes was performed using MM2CS Chem 3D Ultra 11.0 version software and using pm3 programme.

The correct stereochemistry was assured through the exploitation and modification of the molecular coordinates to attain reasonable low energy molecular geometries. The potential energy of the molecule was considered as the sum of the following stipulations:

$$
E=E_{\mathrm{str}}+E_{\mathrm{ang}}+E_{\mathrm{tor}}+E_{\mathrm{vdw}}+E_{\mathrm{oop}}+E_{\mathrm{ele}},
$$

where $E$ represents the energy values corresponding to the given type of interaction ( $\mathrm{kcal} / \mathrm{mol})$. The subscripts str, ang, tor, vdw, oop, and ele signify bond stretching, angle bonding, torsion deformation, van der Waals interactions, out of plane bending, and electronic interaction, respectively. The analytical and spectral studies represent the hexacoordination [Cu(II), $\mathrm{Ni}(\mathrm{II}), \mathrm{Co}(\mathrm{II})$, and $\mathrm{Mn}(\mathrm{II})]$ and tetracoordination $[\mathrm{Zn}(\mathrm{II})$ and $\mathrm{Cd}(\mathrm{II})]$ of the complexes which were further confirmed by their molecular modeling studies.

The 3D optimized geometrical structures of ligand HNMAMQ and its $\mathrm{Cu}(\mathrm{II}), \mathrm{Ni}(\mathrm{II}), \mathrm{Co}(\mathrm{II}), \mathrm{Mn}(\mathrm{II}), \mathrm{Cd}(\mathrm{II})$, and $\mathrm{Zn}$ (II) complexes were presented in Figures 1, 2, 3, $4,5,6$, and 7 . The minimum steric energy which was repeated several times to find out the global minimum 


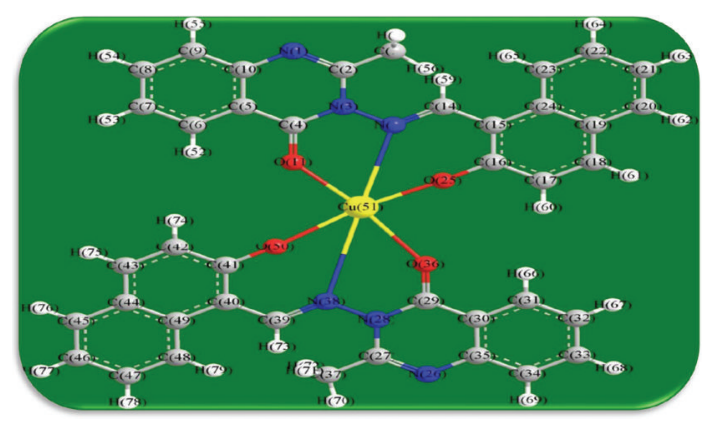

FIGURE 2: Molecular modeling structure of $\mathrm{Cu}(\mathrm{II})$ complex.

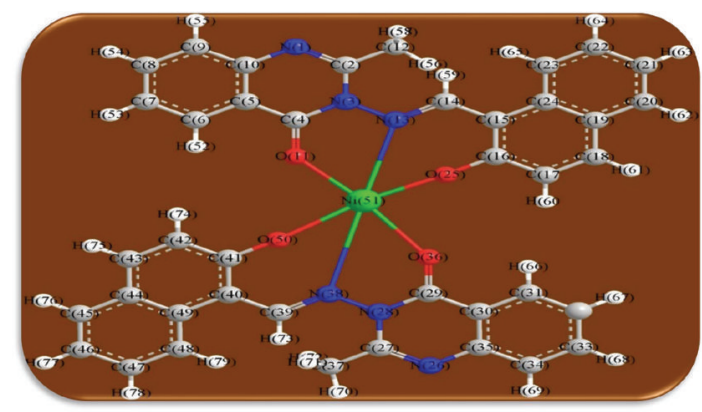

Figure 3: Molecular modeling structure of Ni(II) complex.

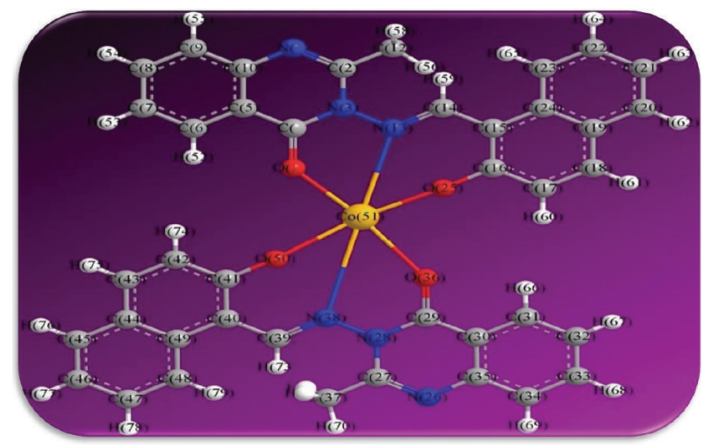

FIgURE 4: Molecular modeling structure of $\mathrm{Co}$ (II) complex.

obtained to be $23.474,122.793,143.906,185.32,128.35,132.639$, and $140.429 \mathrm{kcal} / \mathrm{mole}$, respectively. The obtained bond lengths of the ligand HNMAMQ were in-between $\mathrm{N}(13)$ $\mathrm{C}(14) 1.2150 \AA, \mathrm{N}(3)-\mathrm{N}(13) 1.3552 \AA, \mathrm{C}(4)-\mathrm{O}(11) 1.2610 \AA$, and $\mathrm{C}(16)-\mathrm{O}(25) 1.3550 \AA$. From the analysis of the data in Tables S1-S3 The selected bond lengths and bond angles of optimized ligand HNMAMQ and its complexes were mentioned in Supplementary file (see Supplementary Material available online at http://dx.doi.org/10.1155/2014/817365) calculated for the bond lengths and bond angles, one can conclude the following annotations.

(1) The $\mathrm{N}(3)-\mathrm{N}(13)$ and $\mathrm{C}(4)-\mathrm{N}(13)$ bond lengths become somewhat longer owing/to the coordination with ligand HNMAMQ which takes place via $\mathrm{N}$ atoms of the azomethine $(>\mathrm{C}=\mathrm{N})$ group that was formed on enolization of $(\mathrm{CO})$ group in all complexes

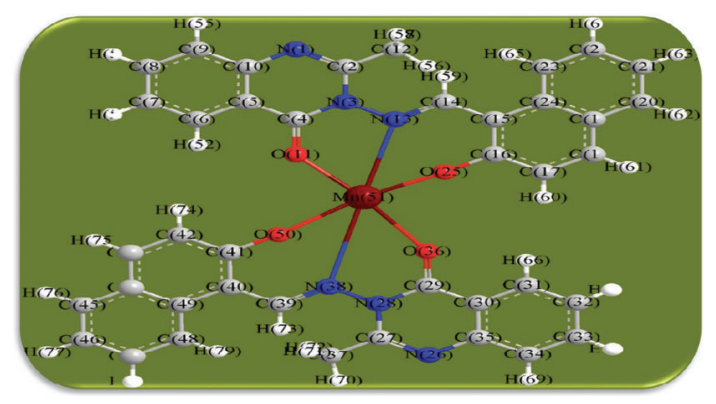

FIGURE 5: Molecular modeling structure of Mn(II) complex.

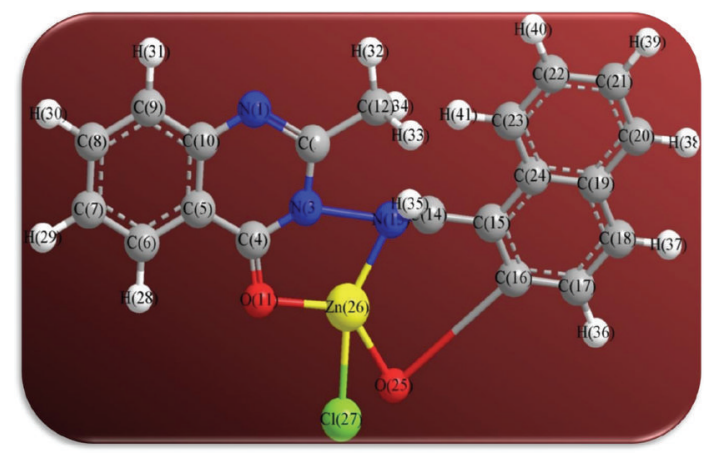

FIGURE 6: Molecular modeling structure of $\mathrm{Zn}$ (II) complex.

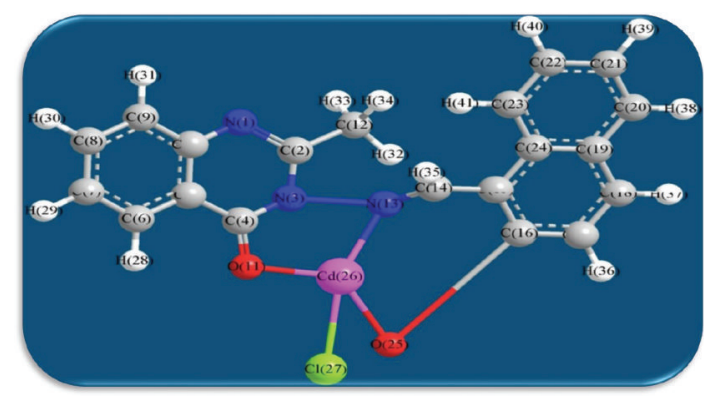

Figure 7: Molecular modeling structure of Cd(II) complex.

[38]. Also, the $\mathrm{C}(4)-\mathrm{O}(11)$ bond distances become longer due to the formation of the $\mathrm{M}-\mathrm{O}$ bond which makes the $\mathrm{C}-\mathrm{O}$ bond weaker [39].

(2) The $\mathrm{Zn}-\mathrm{N}$ and $\mathrm{Cd}-\mathrm{N}$ bond lengths obtained in the present calculations were closer to the earlier reported values to form single crystal $\mathrm{X}$-ray studies to lie between 2.008 and $2.065 \AA$ [40].

(3) In complexes, the $\mathrm{C}(16)-\mathrm{O}(25)$ bond distance becomes longer due to the deprotonation at $\mathrm{N}(13)$ which leads to a higher single bond character for $\mathrm{C}(16)-\mathrm{O}(25)$ result in the formation of the $\mathrm{M}-\mathrm{O}$ bond which makes the $\mathrm{C}-\mathrm{O}$ bond weaker. In addition to that, the $\mathrm{C}(4)-\mathrm{N}(3)$ and $\mathrm{N}(3)-\mathrm{N}(13)$ bond distances were elongated. This refers to the formation of the $\mathrm{M}-\mathrm{N}$ bond which makes the $\mathrm{C}-\mathrm{N}$ bond weaker and forming a double bond character [41]. 
(4) The bond angles in $\mathrm{Cu}(\mathrm{II}), \mathrm{Ni}(\mathrm{II}), \mathrm{Co}(\mathrm{II})$, and $\mathrm{Mn}(\mathrm{II})$ complexes were quite near to an octahedral geometry predicting $\mathrm{d}^{2} \mathrm{sp}^{3}$ hybridization, while $\mathrm{Zn}(\mathrm{II})$ and Cd(II) complexes afforded a tetrahedral geometry predicting $\mathrm{sp}^{3}$ hybridization.

Hence from the above, it was inferred that, when the ligand HNMAMQ containing donor atoms was coordinated with the metal ions by donating a lone pair of electrons results in decrease of electron density on the coordinating atoms, at the same time increase in the bond lengths and bond distance; that is, all the active groups participating in coordination have bonds longer than those already exist in the ligand HNMAMQ (like $\mathrm{C}=\mathrm{N}, \mathrm{C}=\mathrm{O}$, and $\mathrm{O}-\mathrm{H}$ ). Furthermore in most of the cases, the actual bond angles and lengths are close to the optimal values (most favourable), thereby supporting the proposed tetra- and hexacoordinated geometry around the metal ion of these compounds [42].

3.7. Theoretical Structural Models: Surface Area and Charge Density of Ligand HNMAMQ and Its Cu(II) Complex. The solvent-accessible surface (SAS) area is referred as the surface area of a biomolecule that is accessible to a solvent on the other hand the solvent-excluded surface (SES) also known as the molecular surface or Connolly surface, which is imagined as a cavity in bulk solvent effectively the inverse of the solventaccessible surface, generally both are calculated using the "rolling ball" algorithm, but the difference is that in a SAS, the surface is drawn from the centre point of the probe radius, while in an SES, the surface is drawn from the touching point of the probe radius $[43,44]$.

Charge (electron) density is the measure of the probability of an electron being present at a specific location and it is usually found around the atom and its bonds. However, in delocalized or conjugated systems, it covers an entire region; that is, in benzene they are found above and below the planar ring. Molecular modeling software often provides graphical images of electron charge density by representing the presence of high or low electron density in a particular position of molecules because graphically the electron density surface serves as a canvas upon which other electronic properties can be displayed as follows.

(1) The electrostatic potential map (the property of electrostatic potential mapped upon the electron density) provides an indicator for charge distribution in a molecule.

(2) The local ionization potential map (the property of local ionization potential mapped upon the electron density) provides an indicator of electrophilicity.

(3) The LUMO map (lowest unoccupied molecular orbital mapped upon the electron density) can provide an indicator for nucleophilicity [45].

To know the interaction of ligand HNMAMQ and its complexes, we thought of interest to draw the theoretical models of solvent-accessible surface (SAS), solvent-excluded surface (SES), and total charge density especially for the ligand $\mathrm{HNMAMQ}$ and its $\mathrm{Cu}(\mathrm{II})$ complex as shown in

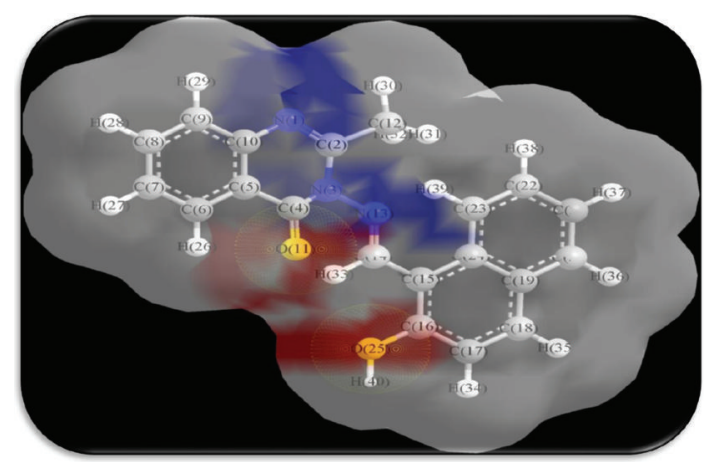

FIGURE 8: Solvent accessible surface of ligand HNMAMQ.

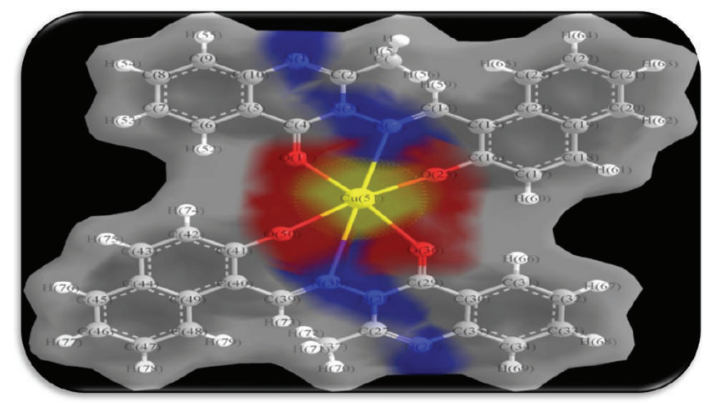

FIGURE 9: Solvent accessible surface of $\mathrm{Cu}(\mathrm{II})$ complex.

Figures 8, 9, 10, 11, 12, and 13. Further calculating their theoretical structural analysis results is our next goal.

\subsection{Biological Results}

3.8.1. DNA Cleavage Studies. All the metal complexes of ligand HNMAMQ were studied for their DNA cleavage activity by gel electrophoresis. From the gel picture study it was clearly observed that all the metal complexes show complete DNA cleavage. The variation in the bands of complexes (lanes I-VI) was observed as compared with control DNA of E. coli. In general, metal complexes upon binding to DNA get stabilized through a series of weak interactions such as the stacking interactions of aromatic heterocyclic groups between the base pairs, hydrogen bonding, and van der Waals interactions of functional groups that bound along the groove of the DNA helix [46]. The DNA cleavage activity was significantly increased by the inclusion of metal ion in the Schiff base. From these results it was accomplished that the control DNA alone does not show any apparent cleavage, whereas its complexes show superior activity and also indicate the vital role of metal ions in these isolated DNA cleavage reactions. However, the nature of the reactive intermediates involved in the DNA cleavage by the complexes is not clear. As the compound was observed to cleave the DNA, it can be concluded that the compound inhibits the growth of the pathogenic organism by cleaving the genome [47]. 


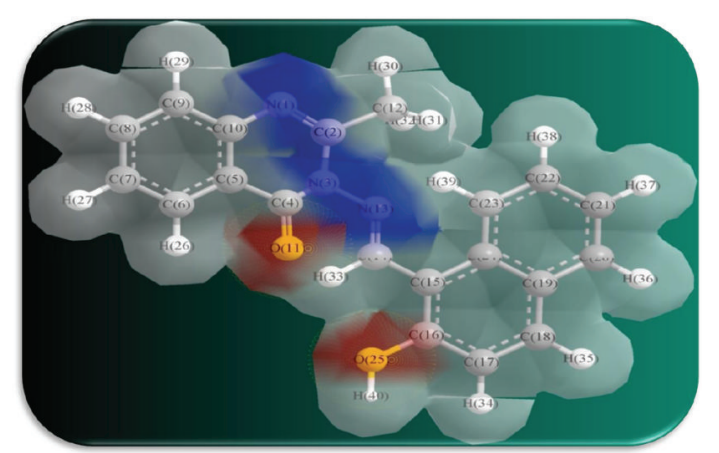

FIGURE 10: Connolly molecular surface of ligand HNMAMQ.

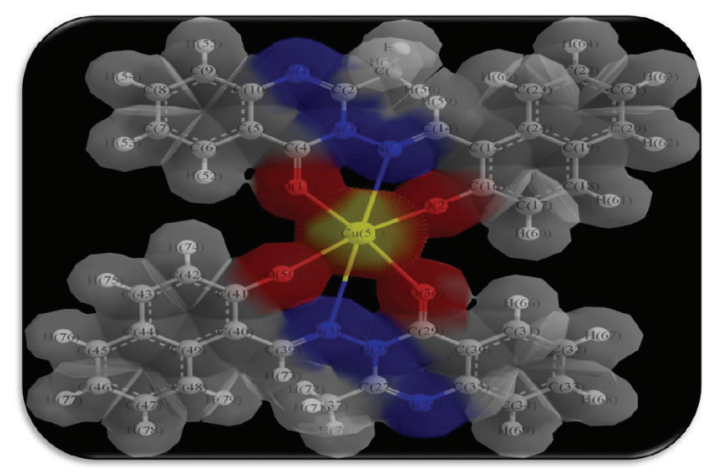

FIgURE 11: Connolly molecular surface of $\mathrm{Cu}$ (II) complex.

3.8.2. In Vitro Antimicrobial Activities. The in vitro antibacterial results reveal that the ligand HNMAMQ and its complexes were found to be potentially active against $E$. coli (MTCC number 1698) and moderately active against S. aureus (MTCC number 7443) and B. subtilis (MTCC number 9878). This may be due to inhibitory activity of ligand HNMAMQ related to the cell wall structure of the bacteria. In general, the membrane of gram-negative bacteria was surrounded by an outer membrane containing lipopolysaccharides. The ligand HNMAMQ appears to be able to combine with the lipophilic layer to increase the membrane permeability of the gram-negative bacteria. Therefore the lipophilicity plays a significant role in causing the death of the gram-negative bacteria [48]. Moreover, the synergistic effect of ligand (HAMAMQ) with metal complexes enhances the antimicrobial activity; this may be explained by chelation theory. On chelation the positive charge of metal is partially shared with the donor atoms present in the ligands; there may be $\pi$-electron delocalization over the whole chelating. This increases the lipophilic character of the metal chelate and favours its penetration through the lipid layer of the bacterial membranes. Chelation is not only the criterion for antibacterial activity; it is expected to be a function of steric, electronic, and pharmacokinetic factors along with mechanistic pathway. Other factors such as solubility, conductivity, dipole moment, size of metal ions, stability constants of the complexes, and their magnetic moments are also reported to affect the microbial activity of the complexes [49]. This enhancement in the activity is also rationalized

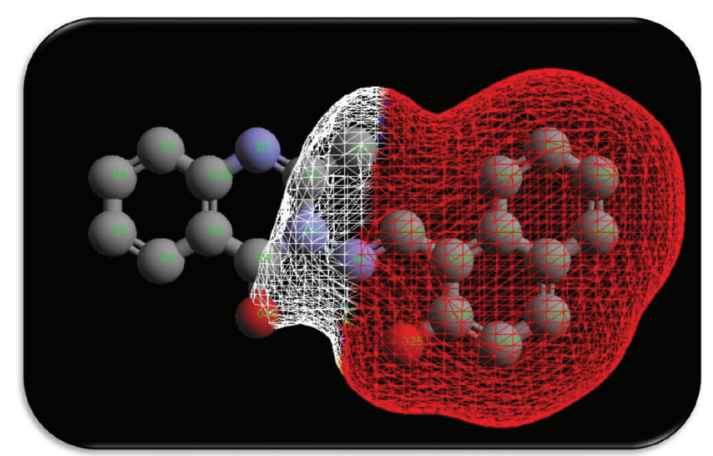

FIgURE 12: Total charge density of ligand HNMAMQ.

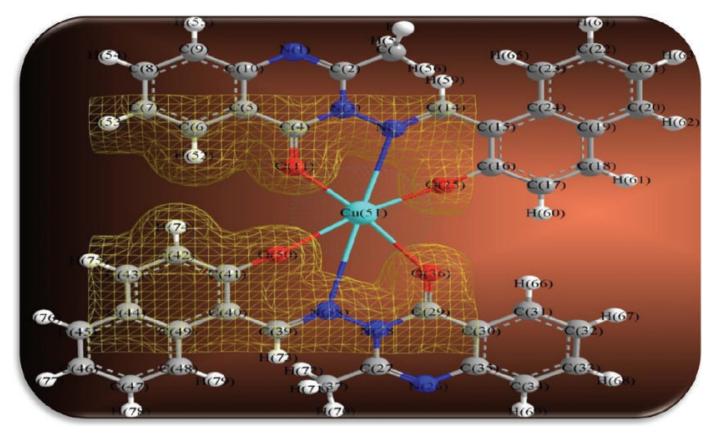

FIGURE 13: Total charge density of $\mathrm{Cu}(\mathrm{II})$ complex.

due to presence of azomethine $(\mathrm{C}=\mathrm{N})$ group; this imports in elucidating the mechanism of transamination and resamination reactions in biological system. In addition to this the formation of hydrogen bonds through the azomethine group with the active centres of various cellular constituents, resulting in interference with normal cellular processes [50]. Furthermore, the ligands with nitrogen and oxygen donor systems might inhibit enzyme production, since the enzymes which require these groups for their activity appear to be especially more susceptible to deactivation by the metal ions upon chelation [51].

In case of antifungal activity, the ligand (HAMAMQ) exhibits good activity against $A$. flavus (MTCC number 277) than A. niger (MTCC number 281). Among all the metal complexes $\mathrm{Cu}(\mathrm{II})$ shows promising activity than the other metal complexes.

Table 4 represents the MIC results of the antimicrobial activities of ligand (HAMAMQ) and its complexes, this shows that $\mathrm{Cu}(\mathrm{II})$ complex shows superior activity, $\mathrm{Ni}(\mathrm{II})$, $\mathrm{Mn}(\mathrm{II}), \mathrm{Cd}(\mathrm{II})$, and $\mathrm{Co}(\mathrm{II})$ complexes exhibit good activity, and $\mathrm{Zn}(\mathrm{II})$ complex exhibits moderate antimicrobial activity. The enhanced activity of $\mathrm{Cu}$ (II) complex can be explained on the basis of their particle size and also may be attributed to its higher stability constants [52].

Thus from the above data, it is of interest to note that some of the mononuclear complexes shows promising activity which interns reflecting the biological efficiency of these complexes, as a useful novel pharmaceutical agents. 
TABLE 4: MIC $(\mu \mathrm{g} / \mathrm{mL})$ of ligand HNMAMQ and its complexes.

\begin{tabular}{|c|c|c|c|c|c|}
\hline Compounds & $\begin{array}{c}\text { S. aureus } \\
\text { (MTCC number } \\
7443)\end{array}$ & $\begin{array}{c}\text { B. subtilis } \\
\text { (MTCC number } \\
9878)\end{array}$ & $\begin{array}{c}\text { E. coli } \\
\text { (MTCC number } \\
\text { 1698) }\end{array}$ & $\begin{array}{c}\text { A. flavus } \\
\text { (MTCC number } \\
\text { 281) }\end{array}$ & $\begin{array}{c}\text { A. niger } \\
\text { (MTCC number } \\
\text { 277) }\end{array}$ \\
\hline $\mathrm{C}_{20} \mathrm{H}_{15} \mathrm{~N}_{3} \mathrm{O}_{2}$ (HNMAMQ) & 45 & 40 & 25 & 50 & 50 \\
\hline$\left[\mathrm{Cu}\left(\mathrm{C}_{20} \mathrm{H}_{14} \mathrm{~N}_{3} \mathrm{O}_{2}\right)_{2}\right]$ & 15 & 20 & 10 & 10 & 15 \\
\hline$\left[\mathrm{Ni}\left(\mathrm{C}_{20} \mathrm{H}_{14} \mathrm{~N}_{3} \mathrm{O}_{2}\right)_{2}\right]$ & 25 & 20 & 15 & 15 & 15 \\
\hline$\left[\mathrm{Co}\left(\mathrm{C}_{20} \mathrm{H}_{14} \mathrm{~N}_{3} \mathrm{O}_{2}\right)_{2}\right]$ & 25 & 20 & 20 & 15 & 20 \\
\hline$\left[\mathrm{Mn}\left(\mathrm{C}_{20} \mathrm{H}_{14} \mathrm{~N}_{3} \mathrm{O}_{2}\right)_{2}\right]$ & 15 & 15 & 15 & 20 & 15 \\
\hline$\left[\mathrm{Zn}\left(\mathrm{C}_{20} \mathrm{H}_{14} \mathrm{~N}_{3} \mathrm{O}_{2}\right) \mathrm{Cl}\right]$ & 35 & 30 & 25 & 45 & 45 \\
\hline$\left[\mathrm{Cd}\left(\mathrm{C}_{20} \mathrm{H}_{14} \mathrm{~N}_{3} \mathrm{O}_{2}\right) \mathrm{Cl}\right]$ & 15 & 15 & 15 & 20 & 15 \\
\hline Gentamicine & 10 & 11 & 10 & - & - \\
\hline Fluconazole & - & - & - & 10 & 10 \\
\hline
\end{tabular}<smiles>CC1=Nc2ccccc2C2O[Al]=Cc3c(ccc4ccccc34)ON=Cc3c(ccc4ccccc34)C(=O)N12</smiles>

$\mathrm{M}=\mathrm{Cu}(\mathrm{II}), \mathrm{Ni}(\mathrm{II}), \mathrm{Co}(\mathrm{II})$, and $\mathrm{Mn}(\mathrm{II})$

Figure 14: Proposed structures of $\mathrm{Cu}(\mathrm{II}), \mathrm{Ni}(\mathrm{II}), \mathrm{Co}(\mathrm{II})$, and $\mathrm{Mn}$ (II) complexes.

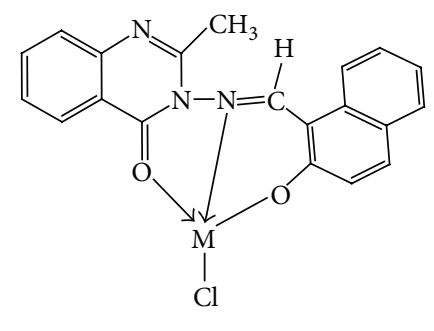

Figure 15: Proposed structures of Zn(II) and Cd(II) complexes.

\section{Conclusion}

In the present study we described the tridentate behaviour of ligand HNMAMQ which forms an octahedral geometry with $\mathrm{Cu}(\mathrm{II}), \mathrm{Ni}(\mathrm{II}), \mathrm{Co}(\mathrm{II})$, and $\mathrm{Mn}$ (II) complexes, whereas tetrahedral geometry with $\mathrm{Zn}$ (II) and $\mathrm{Cd}(\mathrm{II})$ complexes through the involvement of azomethine nitrogen, carboxylato oxygen, and phenolic oxygen donor atoms is based on their analytical, spectral, magnetic, and molecular modeling studies (Figures 14 and 15). The nonelectrolytic nature of the complexes was confirmed on the basis of their molar conductance values.
The DNA cleavage studies revealed that all metal complexes showed good efficiency towards DNA cleavage. In addition to that, in case of antimicrobial activty, the $\mathrm{Cu}$ (II), $\mathrm{Ni}$ (II), $\mathrm{Mn}(\mathrm{II})$, and $\mathrm{Cd}$ (II) complexes show remarkable activity than the ligand HNMAMQ. Therefore, the antimicrobial results are extended to develop new metallodrug as an alternative to existing antibiotics used to treat the drug resistant microbial pathogens. The molecular modeling studies reflect the theoretical important application of these newly synthesized compounds in coordination chemistry that is, in determining the correct bond length, bond angle as well as geometry, and so forth, and also open up the several opportunities to explore the biological potency of these compounds. Hence from all these extensive observations, it was concluded that the ligand HNMAMQ and its complexes give the remarkable, versatile, and valuable information of coordination compounds in analytical and medicinal field and also they may be used as potent biological agents with reduced toxicity and higher efficiency.

\section{Conflict of Interests}

The authors declare that there is no conflict of interests regarding the publication of this paper.

\section{Acknowledgments}

The authors are thankful to the Chairman, Department of Chemistry, Gulbarga University, Gulbarga, for kind guidance and providing laboratory facilities. The author Sunilkumar B. Mane is thankful to UGC-MRP, [F. no. 37-171/2009(SR)] New Delhi, for providing financial assistance.

\section{References}

[1] M. Z. David and R. S. Daum, "Community-associated methicillin-resistant Staphylococcus aureus: epidemiology and clinical consequences of an emerging epidemic," Clinical Microbiology Reviews, vol. 23, no. 3, pp. 616-687, 2010.

[2] H. de Lencastre, D. Oliveira, and A. Tomasz, "Antibiotic resistant Staphylococcus aureus: a paradigm of adaptive power," 
Current Opinion in Microbiology, vol. 10, no. 5, pp. 428-435, 2007.

[3] L. Zhang, D. Pornpattananangkul, C.-M. J. Hu, and C.-M. Huang, "Development of nanoparticles for antimicrobial drug delivery," Current Medicinal Chemistry, vol. 17, no. 6, pp. 585594, 2010.

[4] A. O. Al-Deeb and A. M. Alafeefy, "Synthesis of some new $3 \mathrm{H}$-quinazolin-4-one derivatives as potential antitubercular agents," World Applied Science Journal, vol. 5, no. 1, pp. 94-99, 2008.

[5] H. Mutlu, G. Irez, A. T. Colak, and F. Yilmaz, "Syntheses and characterizations of a novel 1,2,3,4-tetrahydroquinazoline and a Co(III) complex," Journal of Coordination Chemistry, vol. 65, no. 12, pp. 2192-2200, 2012.

[6] A. Nagajothi, A. Kiruthika, S. Chitra, and K. Parameswari, "Fe(III) complexes with Schiff base ligands : synthesis, characterization, antimicrobial studies," Research Journal of Chemical Science, vol. 3, no. 2, pp. 35-43, 2013.

[7] G. Naganagowda and A. Petsom, "Synthesis and antimicrobial activity of some new 2-(3-chloro-1-benzothiophen-2-yl)-3(substituted-phenyl)-4- (3H)-quinazolinones derivatives," Journal of Sulfur Chemistry, vol. 32, no. 3, pp. 223-233, 2011.

[8] D. Sun-Waterhouse, J. Chen, C. Chuah et al., "Kiwifruit-based polyphenols and related antioxidants for functional foods: kiwifruit extract-enhanced gluten-free bread," International Journal of Food Sciences and Nutrition, vol. 60, no. 7, pp. 251264, 2009.

[9] T. Hökelek, N. Gündüz, Z. Hayvali, and Z. Kiliç, "Schiff bases and their complexes with metal ions. Part II. Structures of N-n-butyl-2-hydroxy-1-naphthaldimine and bis[N-n-pentyl-2hydroxy-1-naphthaldiminato]nickel(II)," Journal of Chemical Crystallography, vol. 25, no. 12, pp. 831-836, 1995.

[10] B. K. Singh, H. K. Rajour, and A. Prakash, "Synthesis, characterization and biological activity of transition metal complexes with Schiff bases derived from 2-nitrobenzaldehyde with glycine and methionine," Spectrochimica Acta A, vol. 94, pp. 143-151, 2012.

[11] J. B. Foresman and A. Frish, Exploring Chemistry with Electronic Structure Methods, Gaussian, Pittsburgh, Pa, USA, 2nd edition, 1996.

[12] R. C. Maurya and S. Rajput, "Oxovanadium(IV) complexes of bioinorganic and medicinal relevance: synthesis, characterization and 3D molecular modeling and analysis of some oxovanadium(IV) complexes involving the $\mathrm{O}, \mathrm{N}$-donor environment of pyrazolone-based sulfa drug Schiff bases," Journal of Molecular Structure, vol. 794, no. 1-3, pp. 24-34, 2006.

[13] A. M. Khedr, N. A. El-Wakiel, S. Jadon, and V. Kumar, "Synthesis, spectral, thermal analyses, molecular modeling, and antimicrobial activities of $\mathrm{Cu}$ (II)-complexes with 1,3,4oxadiazole Schiff-base derivatives," Journal of Coordination Chemistry, vol. 64, no. 5, pp. 851-862, 2011.

[14] F. H. Allen, J. E. Davies, J. J. Galloy et al., “The development of versions 3 and 4 of the Cambridge structural database system," Journal of Chemical Information and Computer Sciences, vol. 31, no. 2, pp. 187-204, 1991.

[15] W. J. Geary, "The use of conductivity measurements in organic solvents for the characterisation of coordination compounds," Coordination Chemistry Reviews, vol. 7, no. 1, pp. 81-122, 1971.

[16] K. Siddappa and B. M. Sunilkumar, "Pharmacological activity of (E) 3-2-(1-(1-Hydroxynaphthalen-2-yl) methyleneamino) phenyl) -2-Methylquinazoline-4 (3H) -one Schiff base and its transition metal complexes," International Journal of Pharmacy and Pharmaceutical Sciences, vol. 5, supplement 3, pp. 725-732, 2013.

[17] A. A. H. Al-Amiery, Y. K. Al-Majedy, S. A. Abdulhadi, and A. H. Sadoon, "Design, synthesis and bioassay of novel metal complexes of 3-amino-2-methylquinazolin-4(3H)-one," African Journal of Pure and Applied Chemistry, vol. 3, no. 11, pp. 218-227, 2009.

[18] J. Sambrook, E. F. Fritsch, and T. Miniatis, Molecular Cloning: A Laboratory Manual, Cold Spring Harbor Laboratory Press, Cold Spring Harbour, NY, USA, 2nd edition, 1989.

[19] A. I. Vogel, A Text Book of Quantitative Inorganic Analysis, Longman, London, UK, 3rd edition, 1969.

[20] K. Naresh Kumar and R. Ramesh, "Synthesis, luminescent, redox and catalytic properties of $\mathrm{Ru}(\mathrm{II})$ carbonyl complexes containing $2 \mathrm{~N}_{2} \mathrm{O}$ donors," Polyhedron, vol. 24, no. 14, pp. 18851892, 2005.

[21] N. Raman, R. Jeyamurugan, A. Sakthivel, and L. Mitu, "Novel metal-based pharmacologically dynamic agents of transition metal(II) complexes: designing, synthesis, structural elucidation, DNA binding and photo-induced DNA cleavage activity," Spectrochimica Acta A, vol. 75, no. 1, pp. 88-97, 2010.

[22] M. Muthukumar and P. Viswanathamurthi, "Synthesis, spectral characterization and catalytic studies of new ruthenium(II) chalcone thiosemicarbazone complexes," Central European Journal of Chemistry, vol. 8, no. 1, pp. 229-240, 2010.

[23] A. E.-F. Ouf, M. S. Ali, E. M. Saad, and S. I. Mostafa, "pH-metric and spectroscopic properties of new 4-hydroxysalicylidene2-aminopyrimidine Schiff-base transition metal complexes," Journal of Molecular Structure, vol. 973, no. 1-3, pp. 69-75, 2010.

[24] N. Ohkaku and K. Nakamoto, "Metal isotope effect on metalligand vibrations. VI. Metal complexes of 8-hydroxyquinoline," Inorganic Chemistry, vol. 10, no. 4, pp. 798-805, 1971.

[25] S. Saydam, "Synthesis and characterisation of the new thiazole Schiff base 2-(2-hydroxy)naphthylideneaminobenzothiazole and its complexes with $\mathrm{Co}(\mathrm{II}), \mathrm{Cu}(\mathrm{II})$, and $\mathrm{Ni}(\mathrm{II})$ ions," Synthesis and Reactivity in Inorganic and Metal-Organic Chemistry, and Nano-Metal Chemistry, vol. 32, no. 3, pp. 437-447, 2002.

[26] M. M. Alam, R. Begum, S. M. M. Rahman, and S. M. S. Islam, "Synthesis, spectroscopic and electrochemical studies of mononuclear $\mathrm{Fe}(\mathrm{II})$ and $\mathrm{Ni}(\mathrm{II})$ complexes containing a macrocyclic ligand derived from pyridine-2,6-dicarboxaldehyde and 1,2-Bis(2-aminoethoxy) ethane," Journal of Science Research, vol. 3, no. 3, pp. 609-607, 2011.

[27] T. M. A. Ismail, A. A. Saleh, and M. A. E. Ghamry, “Tetraand hexadentate Schiff base ligands and their $\mathrm{Ni}(\mathrm{II}), \mathrm{Cu}$ (II) and $\mathrm{Zn}$ (II) complexes. Synthesis, spectral, magnetic and thermal studies," Spectrochimica Acta A, vol. 86, pp. 276-288, 2012.

[28] H. Liu, H. Wang, F. Gao, D. Niu, and Z. Lu, "Self-assembly of copper(II) complexes with substituted aroylhydrazones and monodentate N-heterocycles: synthesis, structure and properties," Journal of Coordination Chemistry, vol. 60, no. 24, pp. 2671-2678, 2007.

[29] G. G. Mohamed, M. A. Zayed, and S. M. Abdallah, "Metal complexes of a novel Schiff base derived from sulphametrole and varelaldehyde. Synthesis, spectral, thermal characterization and biological activity," Journal of Molecular Structure, vol. 979, no. 1-3, pp. 62-71, 2010.

[30] A. E. Underhill and D. E. Billing, "Calculations of the racah parameter B for nickel (II) and cobalt (II) compounds," Nature, vol. 210, no. 5038, pp. 834-835, 1966. 
[31] T. Rosu, M. Negoiu, S. Pasculescu, E. Pahontu, D. Poirier, and A. Gulea, "Metal-based biologically active agents: synthesis, characterization, antibacterial and antileukemia activity evaluation of $\mathrm{Cu}(\mathrm{II}), \mathrm{V}(\mathrm{IV})$ and $\mathrm{Ni}(\mathrm{II})$ complexes with antipyrine-derived compounds," European Journal of Medicinal Chemistry, vol. 45, no. 2, pp. 774-781, 2010.

[32] T. Rosu, A. Gulea, A. Nicolae, and R. Georgescu, "Complexes of $3 \mathrm{~d}^{n}$ metal ions with thiosemicarbazones: synthesis and antimicrobial activity," Molecules, vol. 12, no. 4, pp. 782-796, 2007.

[33] K. B. Gudasi, M. S. Patil, R. S. Vadavi, R. V. Shenoy, S. A. Patil, and M. Nethaji, "X-ray crystal structure of the $N$-(2-hydroxy1-naphthalidene)phenylglycine Schiff base. Synthesis and characterization of its transition metal complexes," Transition Metal Chemistry, vol. 31, no. 5, pp. 580-585, 2006.

[34] D. N. Satyanarayana, Electronic Absorption Spectroscopy and Related Techniques, Orient Longman, Chennai, India, 2001.

[35] S. P. Tandon and P. C. Mehta, "Spectral intensities of some $\mathrm{Pr}^{+3}$ $\beta$-diketonates," The Journal of Chemical Physics, vol. 52, no. 8, pp. 4313-4315, 1970.

[36] G. Speier, J. Csihony, A. M. Whalen, and C. G. Pierpont, "Studies on aerobic reactions of ammonia/3,5-Di-terf-butylcatechol Schiff-base condensation products with copper, copper(I), and copper(II). strong copper(II)-radical ferromagnetic exchange and observations on a unique $\mathrm{N}-\mathrm{N}$ coupling reaction," Inorganic Chemistry, vol. 35, no. 12, pp. 3519-3524, 1996.

[37] B. J. Hathaway and D. E. Billing, "The electronic properties and stereochemistry of mono-nuclear complexes of the copper(II) ion," Coordination Chemistry Reviews, vol. 5, no. 2, pp. 143-207, 1970.

[38] O. A. El-Gammal, "Synthesis, characterization, molecular modeling and antimicrobial activity of 2-(2-(ethylcarbamothioyl)hydrazinyl)-2-oxo- $N$-phenylacetamide copper complexes," Spectrochimica Acta A, vol. 75, no. 2, pp. 533-542, 2010.

[39] D. X. West, J. K. Swearingen, J. Valdés-Martínez et al., "Spectral and structural studies of iron(III), cobalt(II,III) and nickel(II) complexes of 2-pyridineformamide N(4)-methylthiosemicarbazone," Polyhedron, vol. 18, no. 22, pp. 2919-2929, 1999.

[40] E. Şahin, S. Ide, A. Ataç, and Ş. Yurdakul, "Structural features of dibromobis(nicotinamide)zinc(II) complex," Journal of Molecular Structure, vol. 616, no. 1-3, pp. 253-258, 2002.

[41] A. A. R. Despaigne, J. G. Da Silva, A. C. M. Do Carmo, O. E. Piro, E. E. Castellano, and H. Beraldo, "Copper(II) and zinc(II) complexes with 2-benzoylpyridine-methyl hydrazone," Journal of Molecular Structure, vol. 920, no. 1-3, pp. 97-102, 2009.

[42] M. Padmaja, J. Pragathi, and C. Gyana Kumari, "Synthesis, spectral characterization, molecular modeling and biological activity of first row transition metal complexes with schiff base ligand derived from chromone-3-carbaldehyde and o-amino benzoic acid," Journal of Chemical and Pharmaceutical Research, vol. 3, no. 4, pp. 602-613, 2011.

[43] B. Lee and F. M. Richards, "The interpretation of protein structures: estimation of static accessibility," Journal of Molecular Biology, vol. 55, no. 3, pp. 379-400, 1971.

[44] F. M. Richards, "Areas, volumes, packing and protein structure," Annual Review of Biophysics and Bioengineering, vol. 6, pp. 151176, 1977.

[45] W. J. Hehre, A Guide to Molecular Mechanics and Quantum Chemical Calculations, Wavefunction, Irvine, Calif, USA, 2003.

[46] P. Kapoor, N. Fahmi, and R. V. Singh, "Microwave assisted synthesis, spectroscopic, electrochemical and DNA cleavage studies of lanthanide(III) complexes with coumarin based imines," Spectrochimica Acta A, vol. 83, no. 1, pp. 74-81, 2011.

[47] A. Kulkarni, S. A. Patil, and P. S. Badami, "Synthesis, characterization, DNA cleavage and in vitro antimicrobial studies of $\mathrm{La}(\mathrm{III}), \mathrm{Th}(\mathrm{IV})$ and VO(IV) complexes with Schiff bases of coumarin derivatives," European Journal of Medicinal Chemistry, vol. 44, no. 7, pp. 2904-2912, 2009.

[48] G. G. Mohamed, M. M. Omar, M. S. A. El-Ela, and A. M. M. Hindy, "Preparation of macrocyclic Schiff-base ligand and antibacterial activities of transition metal complexes thereof," Toxicological and Environmental Chemistry, vol. 93, no. 1, pp. 57-72, 2011.

[49] N. Raman, R. Jeyamurugan, M. Subbulakshmi, R. Boominathan, and C. R. Yuvarajan, "Synthesis, DNA binding, and antimicrobial studies of novel metal complexes containing a pyrazolone derivative Schiff base," Chemical Papers, vol. 64, no. 3, pp. 318-328, 2010.

[50] N. Dharmaraj, P. Viswanathamurthi, and K. Natarajan, "Ruthenium(II) complexes containing bidentate Schiff bases and their antifungal activity," Transition Metal Chemistry, vol. 26, no. 1-2, pp. 105-109, 2001.

[51] Z. H. Chohan, M. Arif, M. A. Akhtar, and C. T. Supuran, "Metal-based antibacterial and antifungal agents: synthesis, characterization, and in vitro biological evaluation of $\mathrm{Co}(\mathrm{II})$, $\mathrm{Cu}(\mathrm{II}), \mathrm{Ni}(\mathrm{II})$, and $\mathrm{Zn}(\mathrm{II})$ complexes with amino acid-derived compounds," Bioinorgic Chemistry and Application, vol. 2006, Article ID 83131, 13 pages, 2006.

[52] S. M. Jadhav, V. A. Shelke, A. S. Munde, S. G. Shankarwar, V. R. Patharkar, and T. K. Chondhekar, "Synthesis, characterization, potentiometry, and antimicrobial studies of transition metal complexes of a tridentate ligand," Journal of Coordination Chemistry, vol. 63, no. 23, pp. 4153-4164, 2010. 

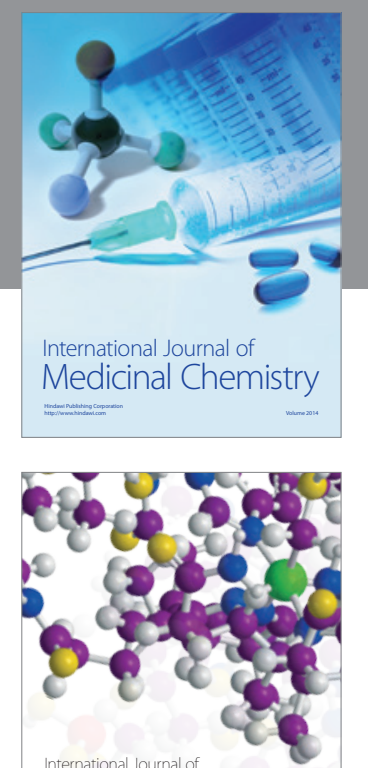

\section{Carbohydrate} Chemistry

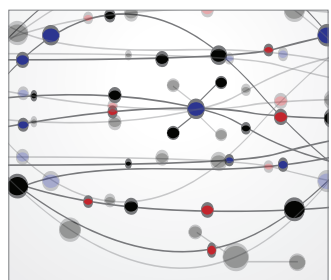

The Scientific World Journal
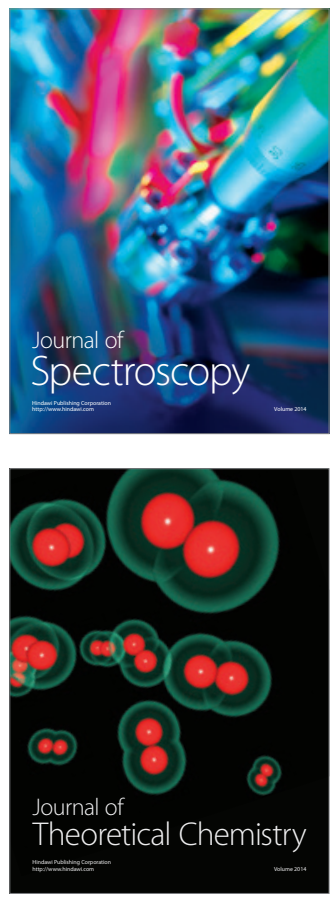
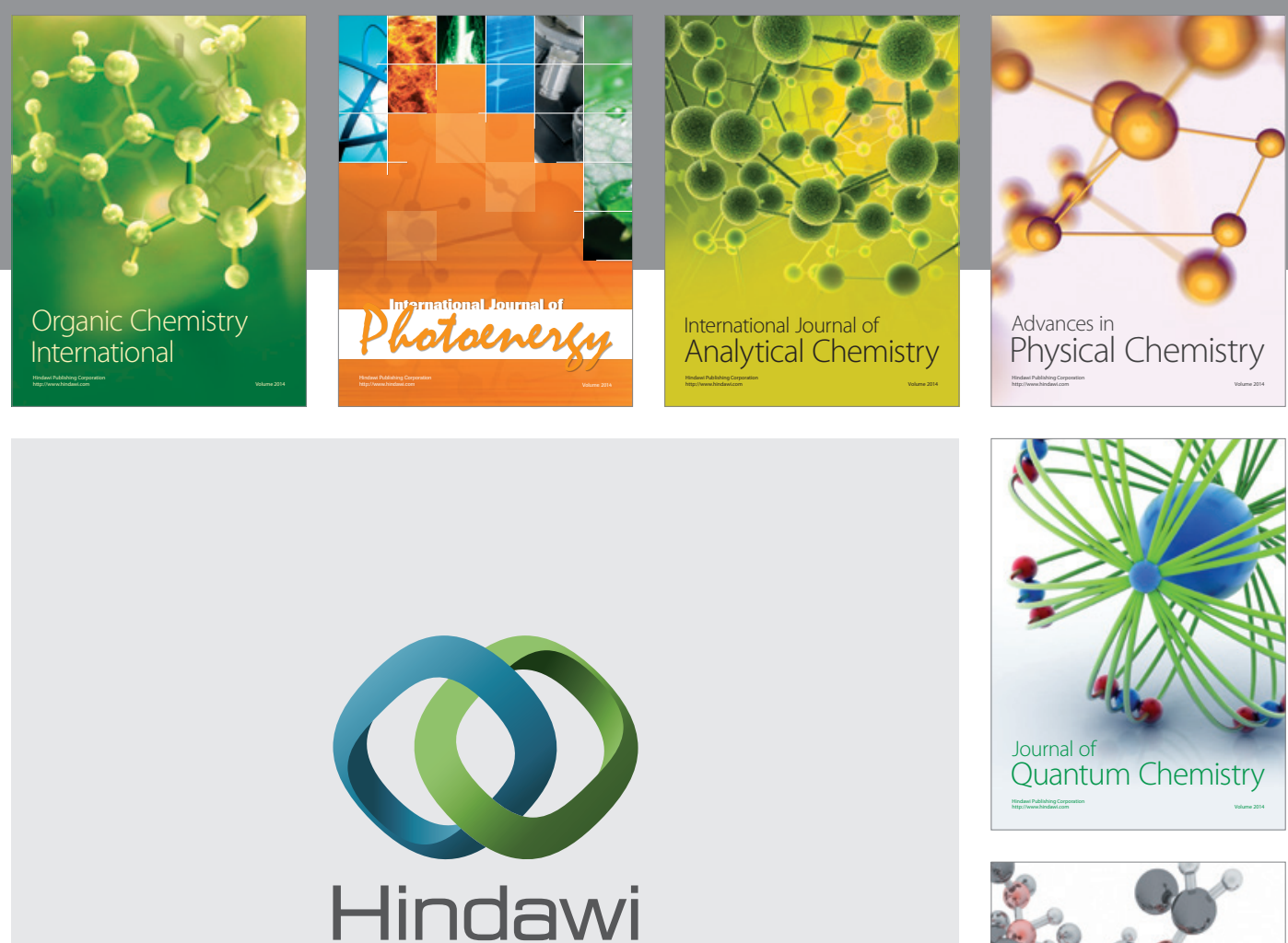

Submit your manuscripts at

http://www.hindawi.com

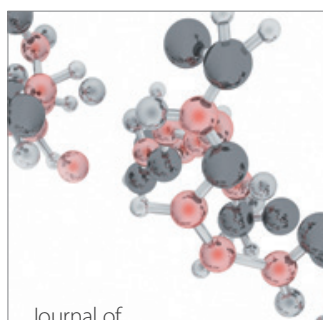

Analytical Methods

in Chemistry

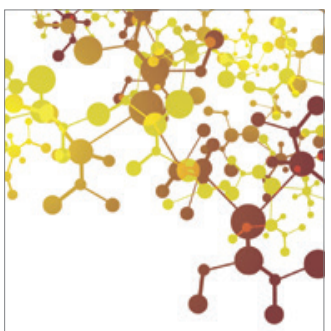

Journal of

Applied Chemistry

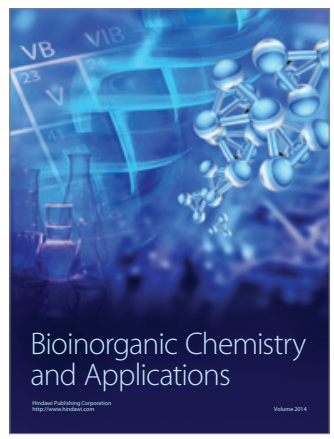

Inorganic Chemistry
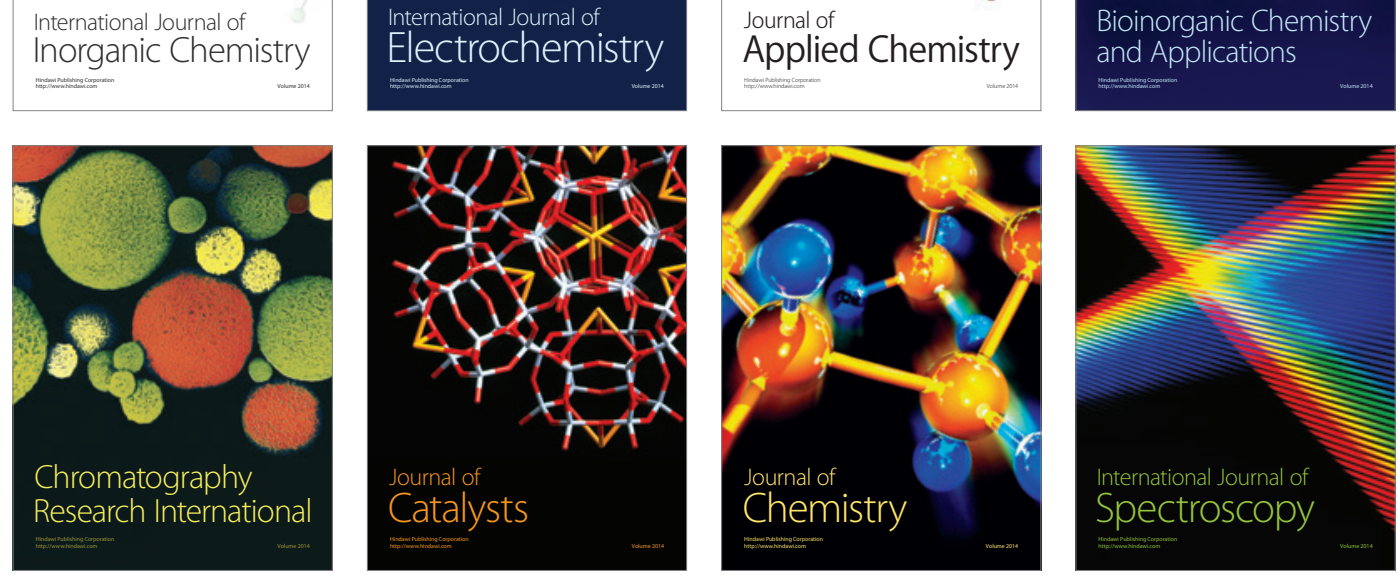